\title{
Development of CENTS-RAS system using PLC improve water quality
}

\author{
Masrul Nizam Mahmod ${ }^{1}$, Mastura Ramli², Ahmad Daud Om ${ }^{3}$ \\ ${ }^{1}$ Department of Mechanical, Politeknik Muadzam Shah, Pahang, Malaysia \\ ${ }^{2}$ Department of Information and Communication Technology, Politeknik Muadzam Shah, \\ Pahang, Malaysia \\ ${ }^{3}$ Marine FinFish Production and Research Center,FRI Tanjung Demong, Terengganu, Malaysia
}

\begin{tabular}{l} 
Article Info \\
\hline Article history: \\
Received Sep 16th, 2020 \\
Revised Oct 11th, 2020 \\
Accepted Oct 23th, 2020 \\
\hline
\end{tabular}

\section{Keyword:}

PLC

RAS Hybrid Grouper

\begin{abstract}
Cheap Efficient Nursery Tank System - Recirculating Aquaculture System (CENTS-RAS) is an alternative hatchery system used in most places in Tanjung Demong Terengganu. Waste trap (Wastrap) is a system on CENTSRAS to dispose of sewage and needs to be opened according to schedule to ensure water quality is at a good level. This requires employees to open the wastrap manually and in an orderly manner. Problems occur when the frequency does not occur regularly. Design and construction smart wastewater controlled by Programmable Logic Controller (PLC) to output electrical actuator ball valve fit in inlet water and wastrap installed in CENTS-RAS for maintaining good water quality. Disposal of dirty water as well as conversion with clean livestock water is systematically controlled based on the programmed time. Previously using manual methods for wastrap opening, fish survival and growth probably limit the production potential is around $78 \%$ $85 \%$. After construction with smart system automatically regular scheduling with 4 time interval methods that have been set will work 24 hours a day for 50 days to ensure the conversion rate and life is high. Effectiveness water quality control were higher by implementing new design using automated methods.
\end{abstract}

(C) 2020 The Authors. Published by IICET.

This is an open access article under the CC BY-NC-SA license (https://creativecommons.org/licenses/by-nc-sa/4.0

\section{Corresponding Author:}

Masrul Nizam Mahmod,

Mechanical Automation Unit, Dep. of Mechanical, Politeknik Muadzam Shah, Pahang, Malaysia

Email: masrul@pms.edu.my

\section{Introduction}

The use of recycling system (RAS) is an alternative to the marine fish hatchery system in the country [1]. And the Department of Fisheries (DOF) that a local technology could be developed a RAS system using local technology that can be developed in marine fish nursery. It is believed to develop a local hatchery with backyard concept, as it is less expensive compared to technology purchased from abroad. The key features of small-scale hatcheries are that they are inexpensive to construct and relatively simple to operate [2]. This why a Cheap Efficient Nursery Tank System - Recirculating Aquaculture System (CENTS-RAS) is developed to meet this need. 
This study was designed to investigate the fish performance nursed in CENTS-RAS facilities focusing on the effect of stocking density on growth in marine fish seeds cultured with water quality system. Moreover, the high water quality is more better it to be identified and better growth performance.

For the manual purpose in CENTS-RAS for tread a water quality is using a manual method are call Waste trap (Wastrap). This system on CENTS-RAS to dispose of sewage and needs to be opened according to schedule to ensure water quality is at a good level. However using a manual method give a problem if the seed more bigger till day one to 50 days nursed hybrid grouper. This because more frequently to open the Wastrap by a time. On 5 week it must regularly open around 4 time a day an having some issue for a night shift.

So because a consideration of time period for 24 hour a day to manage a Wastrap system, therefore have to design and developed a automatic system to control the Wastrap. The design must fullfill the system that can replace the westrap piping 2inch outlet. And a consideration of design a new inlet water to overcome a water drain in tank.

\section{Method}

Through this develop project, Programmable Logic Controller (PLC) is controlled the water for opening and closing the electrical actuated ball valve for westrap and water inlet.[3] Here the PLC start the operation using the Human Machine Interface (HMI) for the interfacing system. By doing schedule for 50days the PLC is doing a automatic system that program four cycle term. Each cycle is consideration of opening the and close the valve how many times in 24 hours.

System programming into PLC to give instruction output. It have 20 valve 2 " for westrap anf 10 valve 1" for water inlet. For one complete task will take an interval of one minute per tank. Instruction by programming for 2 times per day for 12 days, then the second cycle is 4 times per day for 12 days, 3 rd cycle is 8 times per day and last cycle is 10 times per days.

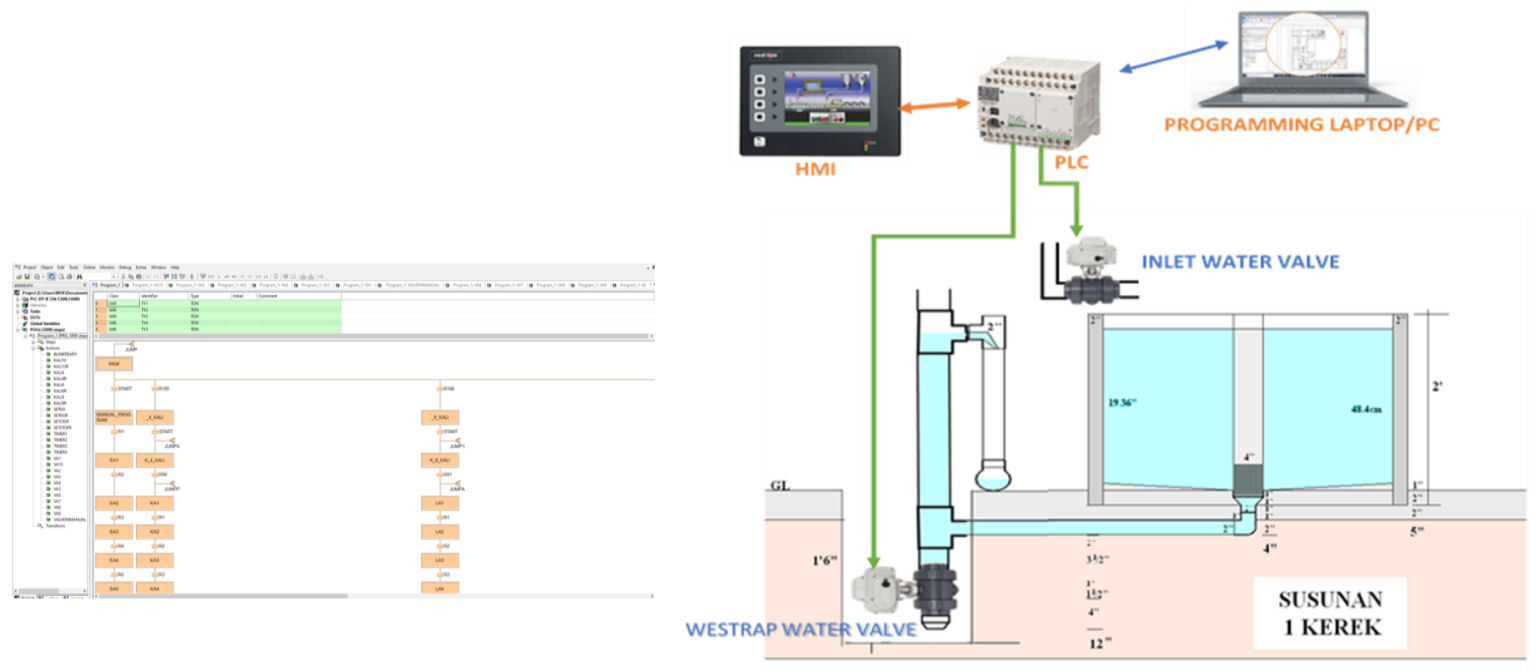

Figure 1 <Design for Programming PLC and System Westrap>

\section{Results and Discussion}

The CENTS-RAS, is a unique efficient system based on back-yard concept, which combines local technologies for land-based recirculating system with simple knowledge technique at medium price. The idea of building CENTS-RAS and equipment is based on very different views on what is important and what is interesting. The idea that used smart automation base on water quality is an indicator of growth of hybrid grouper increasable. Previously using manual methods for wastrap opening, fish survival and growth probably limit the production potential is around $78 \%-85 \%$. After construction with smart system automatically regular scheduling with 4 time interval methods that have been set will work 24 hours a day for 50 days to ensure the conversion rate and life is high base on effectiveness on nursing of fish seed in CENT RAS. 


\section{Conclusions}

CENT-RAS has achieved the targeted production and new design of using a automation system drive by PLC is more efficiency on water quality treatment.[6] This system will give an impact to aquaculture industry in Tanjong Demong.

\section{References}

Department of Fisheries Malaysia, 2019

Ahmad Daud Om, 2012. Asuhan Benih Ikan Marin. Sistem CENTS-RAS, Dewan Bahasa dan Pustaka, Kuala Lumpur. 90 pp.

R. \&. C. Y. Bayindir, "A water Pumping Control System with Programmable Logic Controller (PLC) and industrial Wireless Modules for Indutrial Plants-An Experimental setup," vol. 50, no. 2011, pp. 321328, 2010.

S.M. Khaled Reza, Shah Ahsanuzzaman Md. Tariq, S.M. Mohsin Reza, "Microcontroller based automated water level sensing and controlling: design and implementation issue", Proccedings of the World Congres of Engineering and Computer Science 2010, vol. I, WCECS 2010, San Francisco, USA.

Vijayan, M.M., and Leatherland, J.F. 1988. Effect of stocking density on the growth and stress-response in brook charr. Salvelinus fontinalis. Aquaculture 75: 159-170.

Person-Le Ruyet, J. Labble, L. Le Bayon, N., Severe, A., Le Roux, A., Le Delliou, H., Quemener, L. 2008. Combined effects of water quality and stocking density on welfare and growth of rainbow trout (Oncorhynchus mykiss). Aquat. Living Resour. 21, 185-195. 